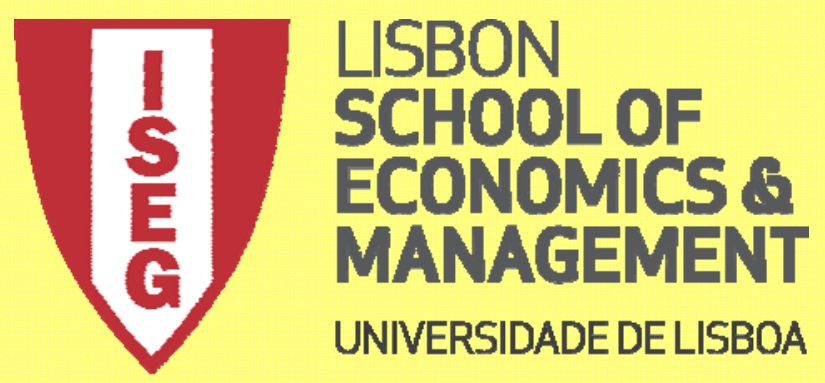

Department of Ec onomics

Ricardo Cabral \& Francisco Louçã

\title{
The euro at twenty: Follies of youth?
}

WP02/2019/DE/UECE

\section{WORKING PAPERS}

ISSN 2183-1815

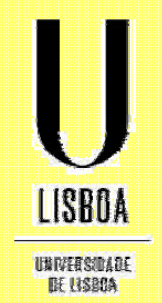




\title{
The euro at twenty: Follies of youth?
}

\author{
Ricardo Cabral $\quad$ Francisco Louçã
}

January 2019

\begin{abstract}
This paper overviews the early history of the euro and argues that the euro was suboptimally designed, without monetary sovereignty of Eurozone (EZ) Member States, in order to comply with political goals set by wealthier Member States. Given this constraint, the euro architects designed a single currency in which its irreversibility is achieved through the EZ banking system, with recourse to the TARGET2 payment system. This allowed the banking systems of deficit Member States to fund large cumulative current account deficits in the first decade of the euro. The euro crisis led EZ policy makers to define new far more demanding fiscal rules and a new Banking Union to constrain the ability of EZ banking systems to fund sovereigns and current account deficits. Thus, the euro at twenty has become more fragile.
\end{abstract}

JEL classification: F45, F32, F34, E62, E52, F36, F42

Keywords: Euro crisis, fiscal rules, banking union, Eurozone, austerity strategy

Ricardo Cabral is assistant professor of Economics at the University of Madeira. He holds a PhD in Economics from the University of South Carolina. His research has been published in Journal of Industrial Economics, Telecommunications Policy and Journal of Banking \& Finance, among others.

Francisco Louçã is full professor of Economics at the Lisbon School of Economics \& Management. He holds a PhD in Economics from the Lisbon School of Economics \& Management. His research has been published in Cambridge Journal of Economics, Industrial and Corporate Change and History of Political Economy, among others.

Correspondence address

Ricardo Cabral, University of Madeira, C. Penteada, 9020-105 Funchal, Portugal. (rcabral@uma.pt)

\section{Acknowledgements}

The views expressed in this paper are the sole responsibility of the authors. The authors gratefully acknowledge financial support from FCT - Fundação para a Ciência e a Tecnologia, I.P., projects number UID/ECO/00685/2016 and UID/ECO/00436/2019. The authors gratefully acknowledge comments from an anonymous referee. The usual disclaimer applies. 


\section{Introduction}

The history of the euro, which just celebrated its twentieth anniversary on the 1 January 2019, can be divided in three phases. The first, which spans decades but that grows in intensity and importance in the 1990s, is its design phase, where the euro was idealized and implemented, and new legislation (e.g., The Maastricht Treaty, the Treaty of Amsterdam, and the Statutes of the ESCB and of the ECB) as well as new institutions (e.g., the ECB) were put in place. The second was, to paraphrase the person widely seen as the 'father of the euro', Otmar Issing (de Grauwe, 2008), its "striking success" phase (Issing, 2008, p. 2), between its launch on January 1, 1998 and late 2009, during which in appearance the euro worked smoothly as the single currency of 11 growing to 16 Eurozone (EZ) Member States, until the outset of the crisis in Greece (Issing, 2008; Buti and Gaspar, 2008). The third is its post euro-crisis phase, which occurs following the 2010-2012 euro crisis as European authorities in a knee-jerk fashion respond not only with the ECB President's, i.e., Mario Draghi's, promise to do "whatever it takes to preserve the euro" in July 2012, which led to a very large quantitative easing programme by the ECB, but also by providing lending with strict conditionality to Member States that were unable to refinance their sovereign debt (Cabral, 2013), and by changing the EZ institutional and legal framework in a dramatic manner (Cabral, 2018) in order to prevent a similar crisis from ever happening again.

In this paper we focus on the third phase and its implications for the future of the euro, but we draw on key elements of the earlier two phases to better understand the constraints faced by the euro as a single currency of 19 EZ Member States, as of the present.

Our key message is that the euro is not only, as widely argued, a straitjacket (Sachs 
and Larrain, 1999; Jespersen, 2004; Otero-Iglesias, 2017), which, while bringing benefits, also imposes non-trivial unnecessary costs on economic activity of EZ Member States (McKinnon, 2002; Ching and Devereux, 2003), but that the euro is also itself in a straitjacket, in that its inherent contradictions, which arise from conflicting and overarching political goals from key EZ decision makers, imperil its use and its survival as the single currency of the EZ.

\section{Brief history}

The euro is a political project as is well known. But it is further the result of political beliefs and the political interests of its architects in the institutions that designed the euro, namely the Monetary Committee (which was later replaced by the Economic and Financial Affairs Committee) and the European Monetary Institute (that preceded the ECB).

Of the complex agenda of those negotiations, for the sake of simplicity and focus, we would emphasize the following aspect. The key challenge faced by the architects of the euro was how to design an irreversible single currency while precluding (significant) fiscal transfers.

Thus, we do not focus here on other more often analyzed 'features' of the single currency, namely the single mandate on inflation targeting of the $\mathrm{ECB}$, nor the stark independence graced upon the ECB, both equally symptomatic of strongly held political beliefs of the euro architects and 'features' on their own right not without implications or consequences, as is well known.

But our argument is that those and other characteristics of the euro architecture are of secondary importance in understanding the key and defining constraints of the euro. 
For the architects of the euro the overriding fear was that the single currency might result in monetary financing of 'profligate' Member States. An interrelated concern was that the euro might become a means to promote fiscal transfers, as key decision makers in wealthier EZ Member States believed and argued that the EZ, like the EU, had to be a Union without (significant) fiscal transfers.

Thus, the architects set out to design a euro that sought to mitigate those fears by minimizing the risk of sovereign debt monetization and of fiscal transfers between Member States.

That is, Member States 'had to be' forbidden from monetizing public debt and from ordering the new EZ central bank (the ECB) from monetizing public debt, and there are various provisions in the European Treaties and in the Statutes of the ESCB and of the ECB to that effect (e.g., Art. 123, 124 and 125 of the TFEU). And the ECB 'had to be' forbidden from direct purchases of Member States public debt in the primary markets or from directly monetizing Member States' public debt (Art. 21 of the Statutes and Art. 123 of the TFEU), though leeway was left in the letter of the articles, if not in the spirit, perhaps unintentionally, which allowed for the ECB to conduct outright purchases of Member States public debt in secondary markets, an interpretation of ECB powers polemic at first, but that grew consensual (Buiter and Sibert, 2005) even before a ruling on the validity of the Outright Monetary Transactions (OMT) programme of the ECB by the European Court following a case put before the German Constitutional Court. $^{1}$

That constraint imposed on the euro by its architects has been recently popularized by de Grauwe and other authors as the lack of monetary sovereignty explanation of

${ }^{1}$ Outright Monetary Transactions case (2014), preliminary ruling of the Court of Justice of the European Union, Judgment of 16 June 2015, Gauweiler, C-62/14, EU:C:2015:400, in response to the referral of two questions of the original case by German Constitutional Court (BVerfGE 134, 366). See also BVerfG, Judgment of the Second Senate of 21 June 2016 - 2 BvR 2728/13. 
the euro crisis (de Grauwe, 2013; de Grauwe and Ji, 2013; Cesaratto, 2015a; Lavoie, 2015; Febrero et al., 2018), in opposition to the thesis that the euro crisis was a balance of payments and external debt crisis (Baldwin and Giavazzi, 2015; Cesaratto, 2013, 2015a, 2015b; Andini et al., 2016). More on this below.

Thus, using present-day terminology and concepts, the key challenge was how to ensure the euro was irreversible, with an 'irrevocable' conversion exchange rate to former national currencies, with no monetary sovereignty of the EZ Member States.

The solution devised by the euro architects was ingenious: to use the EZ banking system to achieve the irreversibility of the euro (Cabral, 2018).

The EZ approach to the single currency has thus important differences to the monetary union of the US. For one, the US Congress is ultimately able to order the Federal Reserve to monetize federal debt. But also the monetary architecture and monetary policy strategy, instruments and procedures differ. For example, unlike in the US in the EZ there is no federal debt that could be used as collateral in liquidity providing repo operations with the central bank and the Federal Reserve does not set a minimum rating threshold (investment grade or A-) to accepting Federal Government debt as collateral. Further, in contrast to the Federal Reserve, the Eurosystem accepted a wide range of financial assets as collateral, including privatesector debt. Finally, some technical features of the EZ TARGET2 payment system differ in significative aspects from the US Inter-District Settlement Account (ISA) payment system (Cabral, 2018).

As a result of the euro design adopted, the EZ Member State banking systems could in theory finance, without limit other than that set by international rating agencies, a 
restriction only imposed from late 2005 onwards, ${ }^{2}$ Member States public budget deficits as well as current plus capital account deficits.

Nonetheless, it is obvious that even during the early years of the euro, the impact of this new regime of the euro was particularly felt as increased vulnerability in the peripheral economies (Damásio et al., 2018).

During the 'striking success' era of the euro (Issing, 2008, p.2), in short, the EZ Member States banking systems performed its designed functions, financing, in practice, nearly without limit, large and recurring current account deficits of some Member States (debtor Member States) mostly with loans from the banking systems of EZ Member States with current account surpluses (creditor Member States). Until 2008, these loans were foremost provided directly between banks through the interbank and the repo market. Following the outset of the Global Financial Crisis (GFC) of 2007-2009, the banking systems of the creditor Member States refused to rollover loans or withdrew deposits from the banking system of debtor Member States, with the ensuing funding gap being financed in a growing degree through Eurosystem regular and Emergency Liquidity Assistance (ELA) refinancing facilities (Cabral, 2012).

While in debtor Member States, nominal GDP and nominal public expenditure grew robustly in this era, particularly in Ireland, less so in Italy, in some Member States the current account deficits were accompanied by public budget surpluses (e.g., Ireland and Spain). In Italy and Portugal, the current account deficits were accompanied by

\footnotetext{
2 On 9 November 2005, an article in the Financial Times ("ECB targets its problem nations", by Ralph Atkins and Mark Schieritz) indicated that the ECB would change its procedures whereby the Eurosystem committed to not accepting securities with ratings below A- as collateral for open market transactions and for the (overnight) marginal lending facility (Buiter and Sibert, 2005). The policy change, first described in the 2006 edition of the annual "ECB General Documentation On Eurosystem Monetary Policy Instruments And Procedures" should be seen in the context of a Financial Times article of 1 April 2005 by Joachim Fels of Morgan Stanley and a May 2005 working paper by Buiter and Sibert (2005), revised in December 2005, pointing out that the format of the ECB open market operations created moral hazard by not discriminating differing risk of Eurozone government bonds.
} 
moderately-sized average budget deficits of $2.9 \%$ and $4.1 \%$ of GDP, respectively, i.e., close to the $3 \%$ of GDP threshold of the Stability and Growth Pact. Greece's average public deficit was significantly higher (6.7\% of GDP).

\section{The euro crisis ill-advised policy decisions}

The EZ decision makers were unprepared for the 2010-2012 euro crisis. The very public dithering and division and a nearly autistic belief by Angela Merkel and Wolfgang Schäuble on the 'no-bailout clause' of the Maastricht Treaty (Art. 125 of the TFEU), in late 2009 and early 2010, almost lead to a chaotic default by Greece. But the effects of such a default on the banking systems of creditor Member States likely contributed to a significant policy change from early 2010 onwards, resulting in the first bailout of Greece in April 2010, which were followed by bailouts of Ireland, Portugal, Cyprus, and Spain's banking system.

Despite the bailout of Greece, the uncertainty about the future of the euro and rise in sovereign debt interest rates resulted in financial contagion foremost to Ireland's, Portugal's, Spain's and Italy's sovereign debt markets.

The narrative that was imposed and prevailed, in part because the banking system funding crisis was hidden from public view through Eurosystem and ELA funding by the national central bank, was that the euro crisis was a sovereign debt crisis, implying that profligate fiscal policy in debtor Member States explained the euro crisis.

Various ad-hoc decisions, namely ECB policy decisions loosely related to 'monetary policy', for example the 2012 Securities Market Programme and the decision to authorize the Central Bank of Ireland to monetize 25 billion euro of Irish government 
long term bonds to substitute ELA financing in February $2013,{ }^{3}$ sought to alleviate financial market conditions or other EZ authorities' concerns.

But the EZ authorities' policy response progressively gained structure and evolved towards a three-pronged strategy (Cabral, 2013).

First, bailout programmes consisting of loans with strict conditionality a la IMF, particularly loans by a new multilateral institution that later became the European Stability Mechanism under the control of the Eurogroup.

Second, accommodative monetary policy response and an ECB waiver of the 2005 A- rating requirement rule for Member States under a bailout programme. The accommodative monetary policy of the ECB ultimately led to the adoption of significant non-conventional policy measures, such as a large quantitative easing programme and negative reference interest rates.

Third, changes in EZ governance with the goal of ensuring that the euro crisis would not occur again and that no fiscal transfers would be necessary. An additional objective was to prevent debtor Member States from unilaterally defaulting or restructuring their sovereign debt, namely sovereign debt restructuring achieved through changes in national laws (Buchheit and Gulati, 2010; Gelpern and Gulati, 2013). The various governance 'reforms' led to a panoply of new legislation and rules, institutions and to further transfer of executive powers from Member States to EZ authorities.

The thrust of the EZ governance changes was to achieve greater central control and command of fiscal policy and of the banking system of debtor Member States.

We focus our analysis on the first and third elements of the EZ authorities' policy response strategy.

${ }^{3}$ Brennan, J. "Central Bank sells further $€ 500 \mathrm{~m}$ of bonds linked to Anglo Irish bailout", The 


\section{The austerity strategy}

The austerity strategy that was adopted in response to the euro crisis is evidently a result of political decisions of key EZ policy makers in office at the time of the events. However, these policy makers sought and obtained a scientific foundation for their policy approach, as evidenced by the presence by Alberto Alesina at an Ecofin meeting in April 2010 (Alesina, 2010) and by explicit references to his research by key EZ policy makers (Chowdhury, 2012). This occurred despite the opposing views of other prominent macroeconomists who argued that such a macroeconomic policy - the austerity strategy - would be counterproductive (Chowdhury, 2012; de Grauwe and Ji, 2013; Blyth, 2013; Stiglitz, 2016) and according to Chowdhury (2012) reflects an "ideological aversion to counter-cyclical fiscal policy" of some EZ policy makers. In fact, an important body of academic literature has focused on the subjects of budgetary adjustments and external adjustments. Alesina and other authors (Alesina et al., 1998, Alesina and Ardagna, 2010) are among the main proponents of the thesis of 'expansionary fiscal austerity' arguing, in particular, that "that fiscal corrections relying mostly on spending cuts that are concentrated on government wages and transfers tend to be expansionary, whereas those relying mainly on tax increases are contractionary" (Alesina et al., 1998).

On the other hand, also favoring the adoption of an austerity strategy, Blanchard and other authors (Blanchard and Muet, 1993; Blanchard, 2007; Blanchard et al., 2013) put forward the thesis of 'internal devaluation', advocating the adoption of a policy of nominal wage cuts in order to respond to crises arising from lack of international competitiveness of countries in a monetary union (or closely linked to one) with high

Irish Times, 15 June 2017. 
current account deficits and high external debt, even though some of the empirical evidence is questionable (Andini, 2008).

There was a recent academic debate on whether the euro crisis was a monetary sovereignty crisis or a balance of payments and external debt crisis (see Febrero et al., 2018, for an overview of the debate).

Nonetheless, in the absence of the ability to command the monetization of sovereign debt into euros, in 2010, several of the debtor Member States had a net external debt position that was very negative, much higher than in prior balance of payment crises. These stocks of debt resulted from the accumulation of recurring and large current account deficits.

Thus, the true primary aim of the austerity strategy was to promote a large external adjustment of debtor Member States that would prevent the further accumulation of current account deficits (Andini et al., 2016). This is the case even if one considers that the adjustment programmes were formally specified in terms of budgetary targets. $^{4}$

On the fiscal front, the Treaty on Stability, Coordination and Governance in the Economic and Monetary Union, TSCG, commonly known as Fiscal Compact, was a intergovernmental treaty quickly put in place. It was signed on 2 March 2012 and went into force on 1 January 2013 (de Grauwe and Ji, 2013). It was complemented by additional pieces of regulation and legislation known as Two-Pack and Six-Pack. These new fiscal rules and procedures were imposed in addition to the rules on budget deficits and debt foreseen in the European Treaties and in the Stability and

${ }^{4}$ Clearly, given the balance of payments accounting identity, a large improvement to the current plus capital account will most certainly also result in a large improvement to the public sector net borrowing requirements. That is, external and budgetary adjustments are partly correlated, but there are significant differences in the aims, policy instruments, and effectiveness of budgetary and external adjustment programmes, as is well known. 
Growth Pact, namely the convergence criteria of the Maastricht Treaty. ${ }^{5}$

In short, the new fiscal rules created four main additional criteria and constraints ${ }^{6}$ on

the budget balance, on public debt levels, on public spending, one or more of which

may be a binding constraint at any one time.

The old and the new fiscal criteria and targets create in combination a de facto EZ quasi-constitutional EZ balanced budget regime "in disguise", which recent EZ reform proposals aim to further strengthen (Bofinger, 2018).

The new fiscal rules also translated in a menu a la carte where different Member States were obliged to comply with different fiscal targets, as was seen in the contrasting reaction of the European Commission to the 2019 Budget Proposals of Italy (initial rejection, for a budget deficit proposal of $2.4 \%$ of GDP, then negotiated for a slight reduction) and of France (approval, for a budget deficit proposal of $2.8 \%$ of GDP, which will likely be revised higher following the 'yellow-vests' protests in France).

5 For a short overview of the Stability and Growth Pact History until 2015 see < https://ec.europa.eu/info/business-economy-euro/economic-and-fiscal-policy-coordination/eueconomic-governance-monitoring-prevention-correction/stability-and-growth-pact/history-stability-andgrowth-pact_en $>$.

${ }^{6}$ In addition to the requirements of a budget deficit of less than 3\% of GDP and public debt close to $60 \%$ of GDP still demanded by the European Treaties (Maastricht Treaty convergence criteria later incorporated in the Stability and Growth Pact), the new rules include the obligations: (i) to reduce by $1 / 20$ the level of public debt above $60 \%$ of GDP each year; (ii) to achieve a structural budget deficit of $0.5 \%$ of GDP each year or be on a convergence path towards this objective, for countries with public debt levels larger than 60\% of GDP; (iii) to improve the structural budget balance regularly and sufficiently rapidly towards a 5-year Medium-Term-Objective (MTO). Both the MTO and the size of the yearly adjustment varies between Member States. The MTO, in theory, should be defined by each Member State, but in practice, it is conditioned by 'minimum targets' defined by the European Commission; and (iv) to ensure that nominal public expenditure, net of some expenditure items, does not grow faster than a upper-threshold estimated by the European Commission for each country on the basis of 10-year estimates of average potential GDP growth, if not accompanied by revenue increasing policy measures. At the same time, tighter and quasi-automatic sanctions and voting procedures have been defined if a member country does not comply with the new rules. 


\section{No more "stealth bailouts"}

But, importantly, the Banking Union was also a key reform that aimed to correct what some policy makers perceived as a 'flaw' or 'loophole' of the euro architecture: Member State banking systems could finance 'profligate' fiscal policy and current account deficits (Cabral, 2018), in practice, almost without limit. The Banking Union also aimed to respond to growing criticism in Germany of "stealth bailout" through the Eurosystem TARGET2 payment system (Sinn, 2011; Sinn and Wollmershäuser, 2011).

The aim was to restrict (debtor) Member States banking systems from promoting excessive credit growth or from financing expansionary fiscal policy, i.e., to finance current account deficits.

This was accomplished by transferring the oversight of the banking systems to a central authority (foremost, the ECB), and by significantly limiting and constraining the policy instruments to respond to failing banks or banks 'in difficulties' through new European legislation (Avgouleas and Goodhart, 2015; Cabral, 2018).

In particular, in the new legislation (foremost, the Bank Recovery and Resolution Directive or BRRD), public bailouts of banks were starkly hindered and various triggers were created that permit or demand public resolution of a bank by authorities (EZ supervisory or resolution authorities in the case of significant EZ banks, which would be the standard procedure) or, if that were not possible, the affected bank would have to be liquidated by national authorities (Cabral, 2018). This could happen regardless of whether the affected bank fully complied with capital requirements regulations.

The liquidation policy instrument should be seen as a 'stick' to induce (debtor) Member States to accept the application of a resolution measure (the 'carrot') by the 
EZ authorities. After all, it makes little economic sense to liquidate a functioning large bank with millions of depositors, particularly if the bank is not technically insolvent.

As a consequence of these features of the legislation, the Banking Union has encouraged bank runs in various EZ member states, which have then served as a basis to trigger the application of a resolution measure. Since 2014 , the EZ has seen the application of several bank resolution measures, particularly in (debtor) Member States, one of which the second largest resolution measure ever, worldwide (Banco Popular in Spain, favoring the concentration of banking assets in Santander).

In response to the Banking Union, banks in the $E Z$, and particularly banks in (debtor) Member States of the EZ, have increased capital levels, reduced NPLs, have been acquired by foreign banks, and in at least some Member States, bank credit has fallen. Importantly, EZ banks are subject to regular stress tests where their exposure to EZ Member States sovereign debt is considered, in breach of Basel III capital requirements rules, thus limiting the ability of banks to finance their respective sovereign (Cabral, 2018).

In sum, the Banking Union legislation, rules, and institutional framework starkly constrain the ability of banks to provide credit to both the private sector and to acquire Member States sovereign debt, in effect limiting the ability of the banking system to finance current plus capital account deficits and to finance the sovereign.

\section{Implications and likely consequences}

The austerity strategy adopted by EZ authorities is both a fiscal austerity strategy a la Alesina et al. and an internal devaluation strategy a la Blanchard et al., but its most significant dimension is related to the latter. The thrust of the austerity strategy is to respond to a balance of payments and external debt crisis, which occur as a 
consequence of the absence of monetary sovereignty by EZ Member States and in the absence of significant fiscal transfers from creditor to debtor EZ Member States (Andini et al., 2016; Febrero et al., 2018).

The focus on maintaining a no fiscal transfers Union with a single common currency means that, for the EZ to function, Member States have to maintain a current plus capital account that is either approximately balanced or in surplus. The austerity strategy adopted by EZ authorities in essence aimed to achieve that goal, thus ensuring no significant fiscal transfers would be necessary.

In fact, the EZ current account balance has risen substantially from $-0.1 \%$ of GDP in 2010 to $+3.2 \%$ of GDP in 2017, with most EZ Member States registering a surplus.

That is, the governance reforms implemented following the euro crisis have reinforced the mercantilist character of the $\mathrm{EZ}$, one where all Member States tend to be 'internationally competitive' surplus countries, i.e., savers rather than borrowers. Therefore, the EZ austerity strategy is akin to replicating the German mercantilist model to the whole of the Eurozone, i.e., to creating a German Eurozone, with recurring large current account surpluses, an approach that the German writer Thomas Mann prophetically warned against in a famous speech in 1953. The consequences of such a strategy are immense, both economically and politically, and are at the roots of the inability of the national and European authorities to manage the successive crises and, thus, are a major factor for the explanation of the rise of resentment and populism.

Clearly, the EZ authorities' austerity strategy only worked because China was willing to reduce its current account surplus since 2010, but the current policy strategy, with current account surpluses in excess of $3 \%$ of GDP, is unsustainable as the EZ economy is much larger than Germany's, and before the euro Germany never dared 
to run very large current account surpluses, namely due to political and commercial pressure from the US government. In the framework of Trump's current aggressive strategy, this option is clearly in risk.

Furthermore, not only is the austerity strategy foolish and unsustainable but the economic cost and the welfare loss have been immense, particularly in the generally less developed (debtor) Member States of the EZ.

In Portugal's case, for example, the external adjustment has been extremely large. The trade balance has improved by 11.2 p.p. of GDP between 2008 and 2017. The current and capital account balance has improved by 12.6 p.p. of GDP in the same period. Portugal, a country of recurring trade deficits for centuries, has registered consecutive trade surpluses since 2012 , nearly as many yearly trade surpluses as in its entire recorded history. The external adjustment was achieved through a drastic reduction in domestic demand, which fell 4.3\% in real terms between 2008 and 2018, with real GDP only in 2018 surpassing the level first reached in 2008. Unemployment, particularly among the young, rose dramatically, though it has recently fallen, since this austerity strategy has been challenged and somewhat changed. Emigration of young cohorts rose substantially affecting the country's demographic prospects.

Still using the Portuguese economy as an example for a simple counterfactual exercise, based on extending the historical nominal GDP growth rate trend of $3 \%$ to between 2008 and $2015,{ }^{7}$ was it good economic policy to forsake $€ 63 \mathrm{bn}$ in nominal domestic demand ( $€ 41$ bn in nominal GDP) in order to improve nominal net exports by somewhat more than $€ 19 \mathrm{bn}$ ?

7 In late 2015 a new government came to power, with parliamentary support of the three leftwing parties, which advocated the end of the austerity strategy. This government promoted the reversal of wage and pension cuts, though maintaining an excessively demanding fiscal consolidation policy strategy in order to comply with the new EZ fiscal rules. 
The bang for the euro seems on the low side... suggesting that the austerity strategy was likely not a very efficient economic policy.

However, the question that we should be making is what happens if a debtor Member State is unable to maintain sufficiently large current account surpluses to be able to service its large legacy external debt.

Clearly, the escape valve of the past, bank financing with recourse to Eurosystem lending (via TARGET2), has been starkly limited through the Banking Union. ${ }^{8}$ But as argued above, it is also the irreversibility of the euro that has been further curtailed with the batch of governance reforms implemented since the 2010-2012 euro crisis. Member States have no monetary sovereignty and their banking systems linkage to the euro has been constrained and weakened.

\section{Conclusion}

The euro always was and still is a political project at twenty. And by this we mean that the political demands on the euro as a currency verge on the impossible.

We are not denying that the euro has had significant successes as a currency. It is used widely, it is trusted as a currency by EZ citizens, it has survived for 20 years and defied its naysayers, particularly in the US. Clearly, it has also had some benefits for economic activity throughout EZ member states, namely greater price transparency, lower transaction costs, better store of value. It may also have anchored inflation expectations better than prior national currencies.

But it has also imposed significant costs, even far beyond what was ever anticipated by its critics, and increasingly it seems that the costs may outweigh the benefits, with

${ }^{8}$ It is not a topic for this paper, but it should be mentioned that the Banking Union itself is and presumably will remain incomplete, since a common mechanism of depositors' guarantee is fiercely opposed by the governments of Germany and other Member States, precisely because it implies the possibility of fiscal transfers in a situation of banking crisis. 
leading policy makers of Member States, like in the newly elected government of Italy, openly defending exit from the euro, even if still not moving in that direction.

It is not just the argument that the euro is a 'straitjacket' on Member States economies, leaving them with no monetary sovereignty, starkly constrained fiscal policy, lack of ability to use exchange rate policy, and now hampered banking systems, to which one should add other EU restrictions such as its competition, state-aid, and industrial policy rules.

It is also the case that the contortions by which EZ policy makers have sought to maintain the euro alive increasingly condition the euro, negatively affecting its normal functions as a currency. ${ }^{9}$

In sum, our main argument is that the euro at twenty has become more fragile and its future does not look promising.

${ }^{9}$ One of us was co-author of a book discussing the concrete implications of the re-creation of a national currency for the case of Portugal, indicating both the relevant difficulties and some measures to counter them (Louçã and Amaral, 2014). 


\section{References}

Alesina, A. (2010) “Fiscal adjustments: Lessons from recent history". Paper prepared for the ECOFIN meeting in Madrid, 15 April.

Alesina, A. and S. Ardagna (2010) "Large changes in fiscal policy: Taxes versus spending". Tax Policy and the Economy, 24, 35-68.

Alesina, A., R. Perotti, and J. Tavares (1998) "The political economy of fiscal adjustments". Brookings Papers on Economic Activity, 197-266.

Andini, C. (2008) "Portugal and the competitive disinflation: Let the data speak". Economics Bulletin, 6, 1-11.

Andini, C., R. Cabral, and F. Louçã (2016) "A policy response to the intra-Eurozone crises". Working paper.

Avgouleas, E. and C. Goodhart (2015) "Critical reflections on bank bail-ins". Journal of Financial Regulation, 1, 3-29.

Baldwin, R. and F. Giavazzi (2015) "Towards a consensus on the causes of the EZ crisis". Voxeu.org, 7 September.

Blanchard, O. (2007) "Adjustment within the euro. The difficult case of Portugal". Portuguese Economic Journal, 6, 1-21.

Blanchard, O., M. Griffiths, and B. Gruss (2013) "Boom, bust, recovery: Forensics of the Latvia crisis". Brookings Papers on Economic Activity, 44, 325-388.

Blanchard, O., and P. Muet (1993) "Competitiveness through disinflation: An assessment of the French macroeconomic strategy". Economic Policy, 8, 11 56.

Blyth, M. (2013) Austerity: The history of a dangerous idea. New York: Oxford University Press.

Bofinger, P. (2018) “'Black zero' in disguise”. VoxEU.org, 13 September. 
Buchheit, L. and M. Gulati (2010) "How to restructure Greek debt". Duke Law Working Papers. Paper 47.

Buiter, W. and A. Sibert (2005) "How the Eurosystem's treatment of collateral in its open market operations weakens fiscal discipline in the eurozone (and what to do about it)". CEPR Discussion paper 5387.

Buti, M. and V. Gaspar (2008) "The first ten years of the euro". VoxEU.org, 24 December.

Cabral, R. (2012) "The roots of the euro crisis lie at the doorsteps of the ECB". Roubini's EconoMonitor, 1 October.

Cabral, R. (2013) "O euro em crise: Cronologia e análise”. In: Palma, C. Paz Ferreira, E., and Torres, H., eds., Estudos em Homenagem ao Professor Doutor Alberto Xavier, Vol. II, Coimbra: Almedina, 635-654.

Cabral, R. (2018) "The Eurozone banking union: Rationale and early experience". Working paper.

Cesaratto, S. (2013) "The implications of TARGET2 in the European balance of payments crisis and beyond". European Journal of Economics and Economic Policy: Intervention, 10, 359-382.

Cesaratto, S. (2015a) "Balance of payments or monetary sovereignty? In search of the EMU's original sin - comments on Marc Lavoie's The Eurozone: Similarities to and differences from Keynes's plan”. International Journal of Political Economy, 44, 142-156.

Cesaratto, S. (2015b) "Alternative interpretation of a stateless currency crisis". Cambridge Journal of Economics, 41, 977-998.

Ching, S. and M. Devereux (2003) "Mundell revisited: A simple approach to the costs and benefits of a single currency area". Review of International Economics, 
11, 674-691.

Chowdhury, A. (2012) "Revisiting the evidence on expansionary fiscal austerity: Alesina's hour?" VoxEU.org, 28 February.

Damásio, B., F. Louçã and J. Nicolau (2018) "The changing economic regimes and expected time to recover of the peripheral countries under the euro: $A$ nonparametric approach". Physica A: Statistical Mechanics and its Applications, 507, 524-533.

Gelpern, A. and M. Gulati (2013) "The wonder-clause". Journal of Comparative Economics, 41, 367-385.

De Grauwe, P. (2008) "On the need to renovate the eurozone". International Finance, 11, 327-333.

de Grauwe, P. (2013) "Design failures in the eurozone: Can they be fixed?" LEQS Paper No 57/2013.

de Grauwe, P. and Y. Ji (2013) "Panic-driven austerity in the Eurozone and its implications". Voxeu.org, 21 February.

Febrero, E., J. Uxó, and F. Bermejo (2018) "The financial crisis in the Eurozone: A balance-of-payments crisis with a single currency?" Review of Keynesian Economics, 6, 221-239.

Issing, O. (2008) The birth of the euro. Cambridge: Cambridge University Press.

Jespersen, J. (2004) "The Stability Pact: A macroeconomic straitjacket!" In: Ljungberg, J., ed., The price of the euro, London: Palgrave Macmillan. Lavoie, M. (2015) "The Eurozone: Similarities to and differences from Keynes's plan". International Journal of Political Economy, 44, 3-17.

Louçã, F. and J. Amaral (2014) A solução novo escudo. Lisboa: Lua de Papel. McKinnon, R. (2002) "Mundell, the euro, and optimum currency areas". In: 
Courchene, T., ed., Money Markets and Mobility, Kingston, Ontario: John Deutsch Institute for the Study of Economic Policy.

Otero-Iglesias, M. (2017) "Italy's struggle with the euro straitjacket". LSE European Politics and Policy (EUROPP) Blog, 16 February.

Sachs, J. and F. Larrain (1999) "Why dollarization is more straitjacket than salvation". Foreign Policy, 116, 80-92.

Sinn, H.-W. (2011) "The ECB's stealth bailout”. VoxEU.org, 1 June.

Sinn, H.-W. and T. Wollmershäuser (2011) "Target loans, current account balances and capital flows: The ECB's rescue facility". CES ifo Working Paper No. 3500.

Stiglitz, J. (2016) The euro: How a common currency threatens the future of Europe. New York: W. W. Norton \& Company. 